\title{
EDUCATION IN SOUTH AFRICA: PRESENT CONSTRAINTS AND FUTURE
}

CHALLENGES

\section{Christopher Colclough and Pundy Pillay}

\section{INTRODUCTION}

Decades of inequality in the provision of education in South Africa have led to a highly differentiated system, with far greater resources being made available, on a per capita basis, to the White population than to the Blacks. This article summarizes the more obvious aspects of existing inequalities, and suggests a set of financing reforms which could be used by a future democratic government to support the educational restructuring which will be required. The analysis focuses upon formal education. The important areas of training and non-formal education are not discussed here.

\section{SOME DIMENSIONS OF EXISTING INEQUALITIES}

\subsection{The school system}

The most striking feature of education in South Africa is racial inequality in terms of both the level and quality of education that is provided. On the one hand, the White population receives a very high level and quality of education, comparable with the best available in the industrially advanced societies. Black education, on the other hand, is characterized by an inequitable allocation of resources, overcrowded classrooms, high drop-out rates and insufficient and poorly-qualified teachers. There are differences even within Black education, with education for Africans suffering the greatest paucity of resources.

This inequality exists in spite of the fact that recent years have seen much sharper increases in real expenditures on Blackeducation than on that for Whites. For example, over the decade 1975-85, real public expenditures on African education increased at an annual average rate of 15 per cent, compared with rates of 9 per cent for Coloureds, 7 per cent for Indians and 3 per cent for Whites. ${ }^{1}$ Similar differentials were maintained over the years to $1991 / 92$ (SAIRR 1992).
As a consequence, enrolments amongst the Black population increased fairly strongly - to produce enrolment ratios among Africans which, by 1985, were slightly ahead of those reported for the rest of Africa (Table 1). This apparent progress, however, was still consistent with enrolment ratios for White South Africans being somewhat higher than those in the advanced industrialized economies - particularly at tertiary level, where almost half of all Whites aged 18-22 were enrolled.

Furthermore, the above picture of apparent progress with Black education needs to be qualified in some important respects. First, those who actually attend school are a smaller number than those who are formally registered. It has been suggested, for example, that in some Natal circuits, more than one half of pupils enrolled have been absent at any one time, over the past few years, owing to violence and instability in that area. Second, there is evidence to suggest that the population estimates provided by the censuses may be too low - particularly those covering the African population. For example, recent rough estimates of the number of children out of school suggest that they may represent between a minimum of 350,000 and a maximum of around 2 million (mainly African) children aged between 6 and 15 years, depending upon which sources for the size of the African population are used. Although the lower of these estimates is likely to prove the more accurate, the range suggests that between 5 and 15 per cent of the 6-15 years age group are out of school at any time 2 .

Third, notwithstanding the real increases in expenditure on schooling for the African population which have occurred, there remains a substantial difference in the resources available to pupils in different population groups. Table 2 shows that, in 1991, public expenditures per pupil for Whites were more than four times greater than those for African children (and almost twice as great as those for children in the Coloured community). Approximately half of

${ }^{2}$ Compare, for example, the estimates of the size of the school-age population given in DBSA 1993 and CSS 1992.

${ }^{1}$ Calculated from Trotter 1988. 
TABLE 1: EDUCATION ENROLMENT RATIOS, 1960 AND 1985 (Per Cent)

\begin{tabular}{|c|c|c|c|c|c|c|}
\hline & \multicolumn{2}{|c|}{ Primary } & \multicolumn{2}{|c|}{ Secondary } & \multicolumn{2}{|c|}{ Tertiary } \\
\hline & 1960 & 1985 & 1960 & 1985 & 1960 & 1985 \\
\hline World & 77 & 99 & 27 & 46 & 6 & 12 \\
\hline Developed Countries & 106 & 112 & 55 & 88 & 13 & 34 \\
\hline LDCs & 60 & 98 & 13 & 38 & 2 & 6 \\
\hline Africa & 44 & 84 & 5 & 33 & $<1$ & 4 \\
\hline South Africa & 78 & 111 & 16 & 56 & 4 & 14 \\
\hline Africans & 77 & 109 & 3 & 49 & 0.7 & 5 \\
\hline Whites & 118 & 115 & 69 & 87 & 18 & 44 \\
\hline Coloureds & 109 & 129 & 15 & 62 & 2 & 7 \\
\hline Indians & 125 & 106 & 23 & 88 & 4 & 24 \\
\hline \multicolumn{7}{|c|}{$\begin{array}{l}\text { Note: South Africa - Primary: refers to sub-A-std-4 and the age group 6-11. Percentages larger than } 100 \text { indicate that } \\
\text { a number of pupils older than } 11 \text { years attended primary school. Secondary: refers to stds } 5-10 \text { and the age group } 12- \\
\text { 17. Tertiary: refers to age group } 18-22 \text {. International: enrolment ratios refer to number of pupils enrolled as percentage } \\
\text { of the appropriate age cohorts in the population. These vary for different countries. Primary education may refer to ages } \\
5-6 \text { to } 11-14 \text {; secondary ranges from ages } 11-12 \text { to } 17-19 \text { and tertiary from ages } 18-20 \text { to } 24 \text {. }\end{array}$} \\
\hline Source: Dostal 1989 & & & & & & \\
\hline
\end{tabular}

these differences were caused by much lower pupil/ teacher ratios in the erstwhile White schools with the remaining differential arising from the teacher salaries in the latter, reflecting the greater average levels of qualification and experience held by the teachers in those schools.
Thus, very substantial differences in the quality of schooling exist between schools which have historically served different population groups. Drop-out rates for African children remain high. For example, among African children who start school, only 13 per cent reach matriculation, less than 3 per cent

TABLE 2: DIMENSIONS OF COST DIFFERENCES IN SOUTH AFRICAN SCHOOLS AND COLLEGES, 1992

\begin{tabular}{|c|c|c|c|c|}
\hline & $\begin{array}{l}\text { Recurrent } \\
\text { Expenditure } \\
\text { (R millions) }\end{array}$ & Pupils & $\begin{array}{l}\text { Unit Cost } \\
\text { (Rands) }\end{array}$ & $\begin{array}{l}\text { Pupil- } \\
\text { Teacher } \\
\text { Ratio }\end{array}$ \\
\hline Whites & 4506 & 1033000 & 4362 & 17.9 \\
\hline Indians & 923 & 256800 & 3594 & 20.9 \\
\hline Coloureds & 2396 & 880800 & 2720 & 22.0 \\
\hline Africans & 7753 & 8113100 & 956 & 39.1 \\
\hline \multicolumn{5}{|c|}{$\begin{array}{l}\text { Note: Enrolments are for each of the racial groups shown, with the exception of the TBVC states, where all pupils } \\
\text { in those regions are shown in the table as Africans. All other data refer to schools administered by the different } \\
\text { departments which had historically served different racial groups. }\end{array}$} \\
\hline \multicolumn{5}{|c|}{ Source: Estimated on basis of data in Department of National Education 1991: Tables 3, 8 and 11} \\
\hline
\end{tabular}


doing well enough to gain a university entrance pass. Equally, whilst 80 per cent of White and Indian pupils entering school may be expected to complete Standard 10 and pass the senior certificate schoolleaving examination, only 20 per cent of Coloured and African children do $\mathrm{so}^{3}$. Not only are pupilteacher ratios much lower in the erstwhile White schools, but similar disparities exist for trained teachers, teaching aids, textbooks and school facilities. There are, therefore, enormous structural problems created by the existing disposition of educational resources which are the result of long years of systematic discrimination against the majority of the population.

\subsection{Inequalities in post-secondary education}

South Africa's tertiary education sector consists of four distinct levels: universities (numbering 21), technikons (15), technical colleges (137) and colleges of education (101). Universities offer the usual range of degree and professional programmes from undergraduate through to doctoral levels. Technikons offer non-degree programmes, largely in technical fields. Technical colleges provide vocational and occupational training for students at both secondary and post secondary levels. Colleges of education train teachers through three- or four-year diploma offerings. Technikons and universities also provide teacher education.

Inequalities of access to post-secondary education are very marked. Table 3 shows that, in 1991, whereas some 60 per cent of Whites aged 18-22 years attended institutions of higher education, this was true of less than 10 per cent of Africans in the same age group. These data confirm that education in
South Africa embraces two distinct worlds: a relatively developed sector which has allowed Whites to progress to tertiary levels with the same frequency as occurs for the populations of the richer industrialized countries, and an underdeveloped sector which has limited African and Coloured participation to levels found in developing countries. The participation of the Asian population in tertiary education has been roughly half way between these two extremes.

While universities are, in principle, free to admit whom they choose, in fact such choice has been constrained by the inability of the secondary education system to provide equal opportunities to aspirant university entrants. The apartheid system has enforced a segregated pre-university education structure which is inferior for Blacks. Thus, the distribution of university students is skewed heavily in favour of Whites. In 1990, for example, 53 per cent of all university students were White, 35 per cent were African, 6 per cent Indian and 6 per cent Coloured (SAIRR 1992), whilst in technikons, 64 per cent of total enrolment was White, 20 per cent African, 8 per cent Coloured and 7 per cent Indian.

The 'open' universities have consistently raised their admission standards, in response to rapidly increasing demand for places. This has tended to exclude Black students. Whilst these universities have introduced compensatory education programmes to help educationally disadvantaged students, access to them has been limited to only a small proportion of African school-leavers. At the University of Cape Town - probably the most liberal of the 'open' universities - the proportion of Black students has been rising, but in the late 1980 s they still only comprised 22 per

TABLE 3: INDICATORS OF ACCESS TO POST SECONDARY INSTITUTIONS, 1991

$\begin{array}{cc}\text { Population Group } & \text { Total PSE enrolments per } \\ 1000 \text { of population }\end{array}$

White

Coloured

Indian

African

Average
Total PSE enrolments as a

proportion of population in

age group 18-22 (percentages)

\section{Source:NEPI 1992}

\footnotetext{
${ }^{3}$ See NEPI 1993: 17-21.
} 
cent of student enrolments whilst African students formed less than 7 per cent of the total. Across the whole system, only 6 per cent of African students were enrolled in the 'open' universities in 1988/89.

The majority of Black university students remain concentrated in the 'tribal' universities which, in many ways, represent an extension of the inferior school education system for Blacks. These institutions have been characterized by poorly qualified staff and low standards and were established to provide credibility for the 'self-governing' and 'independent' homelands. Thus, educational policy on the part of both the state and the liberal educational institutions has ensured a rigid streamlining of access to the university sector: most African students who manage to obtain a university entrance pass do not satisfy the admission criteria for the historically White 'open' universities. There is also a strong subject bias amongst university enrolments which is caused by a large proportion of African matriculants never having studied either mathematics or science. Thus more than 70 per cent of African university students are enrolled either in arts, social science or education faculties. The corresponding figure for Whites in the late 1980s was 34 per cent. Similarly, 5 per cent of African students were enrolled in commerce compared with 17 per cent of Whites, 0.6 per cent were in engineering (Whites 6 per cent), 0.1 per cent were in architecture (Whites 2.1 per cent) and 5 per cent in science (Whites 11 per cent). (CSS 1988).

The racial imbalance of educational opportunity is, if anything, even more marked amongst students attending technikons, than amongst university enrolments. Table 4 shows that amongst those in the post-secondary age group, Whites were 20 times more likely to be attending technikons in 1989 than Africans, whereas they were eight times more likely to be attending universities. These data provide further evidence of the low quality of mathematics / science education for Africans in primary and secondary schools, and of the difficulties they face in taking up technical or science-based careers.

\section{ELEMENTS OF A FUTURE STRATEGY}

\subsection{The macroeconomic context}

The real rate of growth of the South African economy (that is, its growth after taking account of inflation) has been declining for most of the past 30 years from around 6 per cent per year in the early 1960 s to around 1 per cent by the beginning of the 1990 s. Since the population has been increasing at about 2.6 per cent per year, per capita economic growth has been negative since 1982. Employment growth has also deteriorated in line with the long-term economic trend. But since the rate of growth of the population has remained roughly unchanged, the gap between the growth of employment and that of the labour force has increased substantially. Unemployment has, therefore, increased rapidly, and now affects almost one quarter of the labour force. All communities and most families have been affected, but unemployment is concentrated amongst the Black population, and, disproportionately, amongst women and young people. Inequalities in incomes and in access to jobs, education and other public services have remained entrenched.

The causes of the economic decline are complex. In each of the major exporting sectors of agriculture, mining and manufacturing excess capacity increased over the 1980s, and productivity fell. Public and

\section{TABLE 4: NUMBER OF STUDENTS PER THOUSAND OF POPULATION STUDYING AT UNIVERSITIES AND TECHNIKONS, 1989}

\begin{tabular}{|lrc|} 
& \multicolumn{2}{c|}{ Number per thousand } \\
Population Group & Universities & Technikons \\
White & 31 & 10 \\
Indian & 20 & 6 \\
Coloured & 6 & 2 \\
African & 4 & 0.5 \\
& & \\
\hline Source: Pillay 1993, Table 32 & & \\
\hline
\end{tabular}


parastatal sector investments declined from 1980 onwards, but dramatically so (by 50 per cent) over the years 1986-92. Private investment has tended to move closely parallel to that of the government. Thus the reduction in public sector demand in the mid-1980s brought knock-on consequences for the private sector, and business confidence remained weak thereafter. Demand-side solutions, led by the public sector, are, therefore, likely to be important over the short- to medium-term. However, they will need to be carefully managed in the light of the balance-of-payments problems, the large public sector deficit (recently as much as 8 per cent of GDP), and the high levels of domestic inflation which have emerged.

It is clear that an additional important cause of poor economic performance has been the huge inequality in skills which exists across different parts of the labour force - which, in turn are a result of the inequalities which, historically, have imbued economic and social policies. The occupational structure of Black and White workers is highly unequal. Further, although levels of formal education held by the White labour force are high, the labour force as a whole is relatively uneducated compared with other countries at similar stages of development. Labour productivity has been severely impeded by this educational deficit. Skill shortages have been endemic for many years, particularly during the brief cyclical economic upturns which have occurred. Thus a development strategy which affords education and training a central place is needed if sustained growth is to be secured.

\subsection{The major educational priorities}

Basic education will need to be given particular importance. This is necessary on distributional grounds, to secure improvements in access to higher levels of education, to jobs and thus to improvements in the distribution of incomes. But it will also bring more general economic benefits. It is well known that widely spread education and training are important causes of economic growth. Countries with already well-developed education systems grew faster in the 20th century than those which delayed educational development. More recently it has been shown that the rapid grow th of the Asian newly industrializing countries has been centrally influenced by their large stocks of relatively well educated labour. Thus a strategy which emphasizes the acquisition of a good quality basic education by all South Africans is needed to underpin medium-term growth, diversification and export success. It is widely accepted that this basic programme will comprise ten years of schooling which will be both compulsory for all children and free.

The need to secure a reassertion of economic growth in the short-term also places early priority upon achieving improved and expanded supplies of skilled labour. This is required to ease upward pressure on wages as the economy moves back towards full capacity, and will have positive effects upon productivity, and on the growth of national output and employment (including the employment of the unskilled). A dual strategy is needed. Mechanisms to secure and accelerate the upgrading of skills amongst those already employed should be introduced as a matter of urgency, with the private sector being expected to undertake substantially more training of employees than has been the case hitherto. The balance of incentives and sanctions affecting the private sector would need to be re-designed to ensure that this takes place. Secondly, the structure of post-secondary education and training requires reform. Outputs from colleges, technikons and universities will need to be increased gradually, whilst more rapid changes to the structure of enrolments are needed. On the one hand, enrolments should shift more in favour of the previously disadvantaged population groups in South Africa. On the other, the enrolment structure should move sharply towards more technical, scientific and professionally-based programmes than has been the case in the past.

\subsection{Financing issues}

It is clear that the opportunities for desirable public expenditures on the school system in South Africa run the risk of outstripping the resources which are likely to be available over the next few years. Major increases in spending will be needed in order to secure qualitative improvements in those parts of the system which have been historically under-financed, to remove the backlog of school classrooms, to enrol the 5-15 per cent of children who are currently not at primary/junior secondary schools but who are of an age to attend, as well as to cater for the needs of the growing population. Future financing strategy will require imagination and determination if these, and other, needs are to be met. A number of opportunities suggest themselves, which are briefly discussed in the remainder of this article.

The first option is simply to increase the amount of public expenditure on education, in order to finance 
the expansion and qualitative change in education which is required. This is widely judged to be an unpromising solution within South Africa. Publications issued both by the outgoing government and by the democratic movement point to the fact that public spending on education presently amounts to around 24 per cent of the national budget and 7 per cent of national income - proportions which are high by international standards, and which are unlikely to be significantly increased by a new government ${ }^{4}$. On the other hand, national defence expenditure has taken a high proportion of the budget in the past, and some significant reductions can be expected as a consequence of the transition to peace in the southern African region. The needs for reconstruction in other sectors - particularly health and public infrastructure - will also need to be accommodated. But it would require considerable pessimism to argue that education could not expect at least part of the 'peace dividend' which should be available following transition to democratic governance in the new South Africa.

Second, it can be expected that some increase in educational expenditures by the State could be financed from economic growth over the mediumterm. As indicated above, South Africa has been in a deep recession, exacerbated by political uncertainties, since the mid-1980s. The dawning of political stability and the international finance which that is likely to attract, together with an investment strategy led by the public sector, are likely to generate an early return to growth. The public investment programme is likely at least to accommodate the school construction needed to address the backlog of classrooms. However, the additional costs of schooling arising from normal population growth may well absorb most of the increments to budgetary resources arising from economic growth. It is unlikely, then, that resources from growth will be sufficient also to meet the needs for educational restructuring confronting a new government.

A third, and probably a more promising means of financing restructuring, will be via seeking efficiency savings generated within the education system. Repetition rates, for example, are high in many schools, and their reduction would allow perhaps one-quarter of the present out-of-school population

'See Department of National Education 1992: Chapter 24, and NEPI 1993: 55-6. to be enrolled at no net additional cost; reductions in drop-out rates increase costs but, by keeping children in school for the full cycle, earlier schooling benefits are not lost and, in any case, the marginal costs of keeping a child in school are usually much less than those of enrolling new ones; some economies of scale will be able to be captured by moving to a unified system and eliminating the highly inefficient duplication of administrative systems across the 19 departments of education which have existed hitherto; other cost parameters, such as class-size and pupil-teacher ratios should be reviewed and, where necessary, increased to ensure that cost-effectiveness is achieved.

By the same token, however, cost-effectiveness will imply that expenditures will often have to increase. For example, upgrading the professional skills of teachers is critically important for many schools, but ways of doing this without adding significantly to unit costs will be difficult to achieve. Equally, there is at present a very skewed distribution in the different levels of qualified teachers across the various departments. History will thus impose a lack of flexibility upon the practical possibilities for their redistribution. Maintenance costs, too, have been much neglected in many areas, and must rise if minimal environmental standards are to be met. Finally, throughout the school system the relationship between salary and non-salary recurrent expenditures needs to be addressed: in some areas, the latter has declined to intolerably low levels - with attendant losses for effective learning. Thus, the savings that may be available from efficiency reforms are likely to be more than counterbalanced by the costs of the qualitative improvements which are needed throughout the system.

A fourth set of financing options relates to the redistribution of resources away from the presently wellendowed (mainly historically White) education system towards the rest. Some movement in this direction will be inevitable simply because the State could not afford to finance education for all at unit costlevels similar to those currently enjoyed by the White community: simple arithmetic indicates that the costs of so doing would amount to a threefold increase in the current size of the public budget for primary and secondary schooling. Thus, since con-

${ }^{5}$ This follows from the facts that the unit costs of the erstwhile White schools are more than four times those serving the African population, and that African children outnumber Whites by almost 8:1. (See Table 2). 
tinued privileged financing of the erstwhile White schools would be unthinkable, some redistribution will certainly occur.

This has already begun under the outgoing government, whereby schools have had the option of becoming privately owned by their Boards of Governors, as a means of reducing State expenditures on the erstwhile White school system. Nevertheless, the financial impact of privatization is limited owing to the large difference in the sizes of the White and Black school populations. Thus, a reduction of, say, R1000 in the publicly financed unit costs of the erstwhile White schools would allow an increase in spending of only about R100 per African child. Moreover, an unfortunate consequence of this policy would be that the erstwhile White schools would be unlikely to change significantly the racial composition of their enrolments.

Various alternatives are possible. A policy of expanding and desegregating White schools could increase average class size and reduce recurrent costs in the privileged sector. But there are natural limits on the scope for such leavening, imposed by the differential population densities in high and low income areas. Such an approach would need to be combined with increasing the costs borne by highincome parents so as to provide a cross-subsidy to schooling for the rest of the population. It is likely that some mix of these various financing reforms at school level will be used. But none of them, standing alone, would be sufficient to bridge the financing gap which the needs of reconstruction and expansion are likely to bring.

A final set of possibilities are presented at tertiary level, where state expenditures have been high, and where the main beneficiaries have been the progeny of the richer parts of the population. Public expenditures on higher education in South Africa have accounted for about one-fifth of the education budget. It has been estimated that about 70 per cent of these expenditures directly benefit the White community, as opposed to other population groups (Trotter 1988). Since higher education itself brings substantial income benefits to those who receive it, this circumstance has further strengthened the pervasive nature of White privilege in the country. It is likely, then, that the present means of financing higher education in South Africa will be an early candidate for reform. Loan schemes for tertiary studies provide one option. But these provide little budgetary relief in the early years of their operation, and, in other countries, are widely subject to default. However, there are various forms of graduate taxation, levied on either individuals or their employers, which avoid some of these dangers and which appear promising for the achievement of both equity and fiscal objectives.

It seems likely that each of the above options will need to be utilized as part of a new financing strategy for education in a democratic South Africa. The challenge will be to design fiscal measures which redress the legacy of history by bringing education of an acceptable quality within reach of all, and which facilitate the skill development needed for future grow th and prosperity. Educational resources, like most others in South Africa, have been highly maldistributed in the past. Changing this legacy to equip the society for more equally shared growth and development will be a difficult, but by no means impossible task.

\section{REFERENCES}

CSS, 1992, Census of Population 1991, Volume 26, Central Statistical Services, Pretoria

DBSA, 1993, Public Expenditure on Education in South Africa 1987/8 - 1991/2, Development Bank of Southern African, Pretoria, (two volumes)

Department of National Education, 1991, Education Realities 1991, Pretoria 1992, Educational Renewal Strategy, Pretoria

Dostal, E., 1989, 'The long-term future of education in South Africa', Occasional Paper No 15, Unit for Future Research, University of Stellenbosch
NEPI, 1992, Human Resources Development, National Education Policy Investigation, Oxford University Press, Cape Town

1993,Educational Planning, Systems and Structure, National Educational Policy Investigation, Oxford University Press, Cape Town

Pillay, P., 1993, Report on Human Resources Development in South Africa, University of Cape Town (mimeo)

SAIRR, 1992, Annual Survey of Race Relations 1992, South African Institute of Race Relations, Johannesburg

Trotter, G.J., assisted by A.J. Share, 1988,'The social costs of South African education', Economic Research Unit, University of Natal, Durban 